\title{
Collective Action on Forest Governance: An Institutional Analysis of the Cambodian Community Forest System
}

DOI:

10.1016/j.forpol.2017.06.008

\section{Document Version}

Accepted author manuscript

Link to publication record in Manchester Research Explorer

\section{Citation for published version (APA):}

Persson, J., \& Prowse, M. (2017). Collective Action on Forest Governance: An Institutional Analysis of the Cambodian Community Forest System. Forest Policy and Economics, 83, 70-79.

https://doi.org/10.1016/j.forpol.2017.06.008

\section{Published in:}

Forest Policy and Economics

\section{Citing this paper}

Please note that where the full-text provided on Manchester Research Explorer is the Author Accepted Manuscript or Proof version this may differ from the final Published version. If citing, it is advised that you check and use the publisher's definitive version.

\section{General rights}

Copyright and moral rights for the publications made accessible in the Research Explorer are retained by the authors and/or other copyright owners and it is a condition of accessing publications that users recognise and abide by the legal requirements associated with these rights.

\section{Takedown policy}

If you believe that this document breaches copyright please refer to the University of Manchester's Takedown Procedures [http://man.ac.uk/04Y6Bo] or contact uml.scholarlycommunications@manchester.ac.uk providing relevant details, so we can investigate your claim.

\section{OPEN ACCESS}




\title{
Manuscript Details
}

\section{Manuscript number}

Title
FORPOL_2016_120

Collective Action on Forest Governance: An Institutional Analysis of the Cambodian Community Forest System

Article type

Research Paper

\begin{abstract}
Decentralisation in Cambodia has long been propagated as a means to enhance local engagement with governance structures. But in the forestry sector, even limited devolution of powers often constrains local user groups with excessive bureaucratic burdens. In addition, entrenched political economy interests tend to inhibit effective governance. To investigate the apparent institutional malaise that seems to characterise community forestry sites in Cambodia, this study employed a mixed methods approach to evaluate capacities to engage in collective action on forest governance. In our two case studies, community forestry is characterised by the exclusion of younger and poorer households from formal meetings, high costs and limited benefits for members, informal information channels where women and poorer households are excluded, low levels of formalisation, high enforcement costs and massive external pressures. The article calls for community forest entities to develop locally-adapted graduated sanction mechanisms through the receipt of greater support for internal monitoring and enforcement.
\end{abstract}

Keywords

Corresponding Author

Corresponding Author's Institution

Order of Authors

Suggested reviewers
Community forestry policy; Cambodia; natural resource management; collective action; institutions.

Martin Prowse

Lund University

Joel Persson, Martin Prowse

Thomas Sikor, William Sunderlin, Frank van Laerhoven, Ole Mertz

\section{Submission Files Included in this PDF}

\section{File Name [File Type]}

Covering letter - FPE 08-06-17.doc [Cover Letter]

Response to reviewer - FPE - 08-06-17 Revision 1.docx [Response to Reviewers]

Forest Policy and Economics - 08-06-17 Highlights.docx [Highlights]

Forest Policy and Economics - 08-06-17 Abstract.docx [Abstract]

Forest Policy and Economics - 08-06-17 Title page with author details.docx [Title Page (with Author Details)]

Forest Policy and Economics - JP and MP changes 08_06_2017 Revision 1_v3.docx [Manuscript (without Author Details)]

To view all the submission files, including those not included in the PDF, click on the manuscript title on your EVISE Homepage, then click 'Download zip file'. 
Department of Human Geography

Lund University

Sölvegatan 10

SE-223 62 Lund, Sweden

martin.prowse@keg.lu.se

$8^{\text {th }}$ June 2017

\section{Collective Action on Forest Governance: An Institutional Analysis of the Cambodian Community Forest System}

\section{Dear Professor Giessen}

Please find attached a revised manuscript to be reconsidered for publication in Forest Policy and Economics.

We believe we have attended to the excellent comments received from the editorial board and the referee. We would be grateful for a further chance to revise the manuscript if you deem this is necessary.

The paper is not under consideration for publication in another journal or book. All persons entitled to authorship have been named.

We look forward to receiving your decision on this revised manuscript.

Yours sincerely

Martin Prowse 


\title{
Reply to Referee Report on Manuscript FORPOL_2016_120
}

\author{
'Collective Action on Forest Governance: An Institutional Analysis of the \\ Cambodian Community Forest System'
}

\begin{abstract}
We thank the editor for offering us the possibility to improve our paper and we thank the referee for their helpful comments. We have made changes to accommodate the general and specific comments that were put forward. Please find below a copy of all the original comments/questions raised by the editor and the referee, together with our reply to each comment/question. We hope we have covered all queries satisfactorily and have addressed the remaining concerns. If not, we would be grateful for a further opportunity to improve the manuscript.
\end{abstract}

\section{Reply to comments from the editor}

Comment 1: The editorial board suggests to make more explicit how wider Cambodian political environment shape collective actions in community forestry.

Reply 1: We thank the editorial board for this insightful comment. We have now added two paragraphs in the introduction on the political environment and its impact on collective action. 


\section{Reply to comments from Referee \#1}

Comment 1: I have read the manuscript with great interest. The paper identifies a relevant knowledge gap - i.e. the problem statement seems appropriate. The research questions are logically derived from and therefore connected with the problem statement: (i) to what extent does $C F$ creation \& development lead to high rates of participation and awareness among local users, and (ii) to what extent does CF formalization facilitate the emergence of durable institutions for collective action.

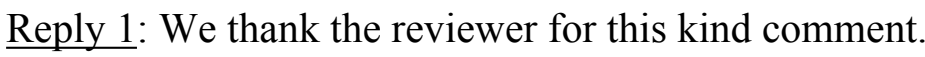

Comment 2: The theoretical chapter seems to mobilize the sources that matter in this fieldthe authors' understanding of the relevant literature is subsequently translated into a conceptual framework that seems to capture the preceding narrative in a structured and organized manner.

Reply 2: We again thank the reviewer for this generous comment.

Comment 3: The methods section then introduces some details that regard the (iterative) research design, and the methods for analyses that were applied. The findings chapter first gives a brief overview of a qualitative comparative analysis of $C F$ in two sites, $A \& B$. It then continues to present the results of a quantitative analysis that aims at determining the likelihood of (i) CF meeting attendance, and (ii) being informed about CF activities. In chapter 6 the findings are discussed (e.g. in terms of variation in individual incentives, costs $\&$ benefits, access to information). In the discussion, recommendations are proposed, based on the outcomes (e.g. linking individual CF sites to the local government system; support organization should focus on enhancing collective action capacity, rather than on technocratic formalization; etc.)

Reply 3: And once again we thank the reviewer for this summary of the middle and latter stages of the paper. 
Comment 4: My main concern regards the disconnect between the sections - in particular:

- the conceptual framework doesn't seem to completely serve as the guiding principle for designing the methodological approach;

Reply 4: We thank the reviewer for this observation. We have now included a revised, condensed conceptual framework and have added an explanation at the end of this section on the methodological approach for the two research questions within the conceptual framework.

Comment 5: - the findings only speak to the conceptual framework to a rather limited extent

Reply 5: We thank the reviewer for this comment. The new condensed framework now means the findings relate more directly to the concepts utilised.

Comment 6: the qualitative part and the quantitative part of the results section also seem unconnected to a certain extent: The qualitative analysis shows variation between site $A$ and $B$ on a range of measures; the quantitative part doesn't really set out to explain that variation (at least not all of it), but looks to estimate the likelihood of attending meetings and being informed about $C F$, without differentiation between sites $A$ and $B$.

Reply 6: We thank the reviewer for this insightful comment. The methods section now includes an explanation that quantitative and qualitative components were designed to address each question separately.

Comment 7: the discussion seems to partly put the findings in the context that is painted by means of the conceptual framework, but does so in a speculative way (i.e. this attempt is not fully informed by the empirical results)

Reply 7: We thank the reviewer for a further insightful comment. We have now improved the discussion to make the links between our empirical findings and the condensed conceptual framework clearer.

Comment 8: the recommendations presented in the conclusion are not explicitly or clearly informed by the results, but seem to be based mostly on the conceptual framework (that unfortunately didn't get fully validated by means of the empirical analysis.

Reply 8: We thank the reviewer for this comment. We have removed the paragraph on local government links since the empirical results do not speak directly to this issue. We have retained the other recommendations as these do stem from the empirical analysis. 
Comment 9: The author(s) could maybe try and do the following: - Start from what you know - i.e. the results. From your empirical analysis you can derive that (i) sites $A$ and $B$ differ, and (ii) a number of explanatory variables determine the likelihood of individuals attending meetings and feeling informed.

Reply 9: We thank the reviewer for this summary of the findings.

Comment 10: Draft a problem statement that you know you can speak to, based on the results that you have - something like: We don't know why there is variation across villages/sites with regard to getting on board of attempts to formalize CF in Cambodia (or elsewhere maybe add this, in order to make this relevant on a more general level)

Reply 10: We thank the reviewer for this suggestion. As the manuscript has identified a relevant knowledge gap and has an appropriate problem statement (see Comment 1 above), we have not altered the research questions the manuscript investigates. However, we have altered the narrative in the introduction to reflect the reviewer's concerns.

Comment 11: Present your understanding of the literature on this topic, but confine yourself to drafting a conceptual framework that is more directly in line with what you are going to present as your empirical basis - i.e. now much of the framework doesn't play any role in the analysis, and is only (partly) revisited in the discussion and conclusion (when you present recommendations). As an empirical basis for validation of your framework lacks, your explicit and implicit references to the framework remain fairly speculative.

Reply 11: We thank the reviewer for this comment. As Reply 4 above states, we have now simplified the conceptual framework (see the new Figure 1) and revised the text in this section of the manuscript.

Comment 12: Then you could draft a methods section that is more explicitly guided by a newly designed framework: (i) tell more about the sample selection strategy (why Cambodia, why the two sites you picked - can these choices be methodologically justified?), (ii) be more specific about operationalizing (indicators!) the elements in the model or framework (specifically, the fact that you do not justify and explain why and how you have measured the specific set of explanatory variables that you use in your models, is problematic, (iii) maybe be a little bit more specific about the data collection methods (instruments!) - again explain, but more importantly, justify, and (iv) there needs to be something on your methods of analysis - now, you cover that for the quantitative part, but you are less detailed about the way in which you have done your analysis for the qualitative part. 
Reply 12: We thank the reviewer for these four points. On the first point, we have now added an explanation for why the province and two CF sites were chosen. On the second point, we have now described in the main text the quantitative indicators used. On the third point we believe we have now added sufficient detail about the data collection methods. Finally, we have complemented our explanation of the quantitative analysis with a better explanation of the qualitative analysis.

Comment 13: Present the results. Present the discussion, and the conclusion - but make sure the recommendations are more explicitly in line with the outcome of your analysis.

Reply 13: We thank the reviewer for these final suggestions. As explained in Reply 8 above, we have removed the paragraph on local government but have retained the other recommendations as these do stem from the empirical analysis. 
- Primary quantitative and qualitative data from two community forests

- Younger and poorer households marginalized in formal meetings

- Women and poorer households excluded from informal information channels

- Durability of CFs highly uncertain

- Better support for locally-adapted graduated sanction mechanisms could improve enforcement 


\begin{abstract}
Decentralisation in Cambodia has long been propagated as a means to enhance local engagement with governance structures. But in the forestry sector, even limited devolution of powers often constrains local user groups with excessive bureaucratic burdens. In addition, entrenched political economy interests tend to inhibit effective governance. To investigate the apparent institutional malaise that seems to characterise community forestry sites in Cambodia, this study employed a mixed methods approach to evaluate capacities to engage in collective action on forest governance. In our two case studies, community forestry is characterised by the exclusion of younger and poorer households from formal meetings, high costs and limited benefits for members, informal information channels where women and poorer households are excluded, low levels of formalisation, high enforcement costs and massive external pressures. The article calls for community forest entities to develop locallyadapted graduated sanction mechanisms through the receipt of greater support for internal monitoring and enforcement.
\end{abstract}

Keywords: Community forestry policy, Cambodia, natural resource management, collective action, institutions. 


\section{Collective Action on Forest Governance: An Institutional Analysis of the Cambodian Community Forest System}

Joel Persson and Martin Prowse *

\footnotetext{
* Both authors are affiliated to the Department of Human Geography, Sölvegatan 10, 223 62, Lund University, Lund, Sweden. Prowse is the corresponding author (martin.prowse@keg.lu.se). Both authors wish to thank SIDA for a Minor Field Study scholarship provided to Persson.
} 


\section{Collective Action on Forest Governance: An Institutional Analysis of the Cambodian Community Forest System}


Decentralisation in Cambodia has long been propagated as a means to enhance local engagement with governance structures. But in the forestry sector, even limited devolution of powers often constrains local user groups with excessive bureaucratic burdens. In addition, entrenched political economy interests tend to inhibit effective governance. To investigate the apparent institutional malaise that seems to characterise community forestry sites in Cambodia, this study employed a mixed methods approach to evaluate capacities to engage in collective action on forest governance. In our two case studies, community forestry is characterised by the exclusion of younger and poorer households from formal meetings, high costs and limited benefits for members, informal information channels where women and poorer households are excluded, low levels of formalisation, high enforcement costs and massive external pressures. The article calls for community forest entities to develop locallyadapted graduated sanction mechanisms through the receipt of greater support for internal monitoring and enforcement.

Keywords: Community forestry policy, Cambodia, natural resource management, collective action, institutions. 
1. Introduction

As a backlash against the dominant centralised model for natural resource management that co-evolved with European state formation (Larson \& Pulhin, 2012), a 'decentralisation euphoria' emerged in the 1990s as part of a normative agenda of political empowerment (Andersson \& Ostrom, 2008, p. 72; Ribot, 2002; Tucker \& Ostrom, 2005). By the end of the 1990s, nearly all developing countries claimed to be pursuing some form of decentralisation policy (Agrawal, 2001b). Decentralisation, nominally understood as the transfer of formal decision-making powers from central to sub-national political bodies, is characterised by a highly complex, nuanced and gradual process of substantiating formal powers through the construction, reformation and consolidation of institutions at different levels of the rulemaking and enforcement hierarchy. Larson \& Soto (2008, p. 216) define democratic decentralisation as the transfer of powers to lower-level government bodies which "involves representative and downwardly accountable local actors who have autonomous, discretionary decision-making spheres," while deconcentration involves the "transfer of powers by central ministries to their branch offices located outside the capital." Devolution, on the other hand, refers to the transfer of specific powers and includes a broader set of options including powers granted to community entities in a co-management regime. In a co-management regime, therefore, property rights are shared between state and community entities (Berkes, 2010; Cronkleton, Saigal, \& Pulhin, 2012).

Decentralisation and deconcentration frame the Government of Cambodia's (RGC) agenda for democratisation and inclusionary development by devolving powers to locally elected Commune Councils (CC) (RGC, 2010). In theory, these political bodies have autonomous decision-making rights, including for natural resource management (RGC, 2008, article 39). However, despite being a primary recommendation of the Independent Forest Sector Review of 2004 (IFSR, 2004; Nathan et al., 2006), forest stewardship functions are completely excluded from Commune Council jurisdictions (Higginson, Bandeth, \& Sopheap, 2013). Instead, a corollary system of Community Forest modalities, based on a complex regulatory framework that was finalised in 2006 (Forestry Administration, 2006), provides the channels for institutionalising democratic decision-making and devolving rights over forest governance to local communities. Local efforts at establishing Community Forests often meet considerable resistance. This is partly a result of rapid deforestation taking place across the country, which has had profound implications for rural populations who rely heavily on forest resources for livelihoods ((Chan \& Sasaki, 2014; Ehara et al., 2016; GERES, 2015). Driven by a complex set of factors rooted in the political economy of the forestry sector (FAO, 2010; Hor et al., 2014; Forests Trends, 2015), deforestation has been enabled through the gradual construction of a state "built on patronage, corruption and coercion" (Miranda \& Kool, 2007, p. 10) through which the political and economic elite "consolidated its power by reorganising productive networks outside formal governance" (Billon, 1999, p. ii). Today, these patronage 
networks exert substantial influence over the allocation of illicitly appropriated benefits arising from the forestry sector (Milne, 2015; Un \& So, 2009).

Although sophisticated legal frameworks for safeguarding citizens' rights exist, implementation and substantiation of rights remains weak (Davis et al., 2015), and formalisation processes tend to legitimise dispossession and disenfranchisement of rural populations (Park, 2015; Work, 2015). Conditions for collective action in Cambodia are thus heavily constrained (Weingart and Kirk 2008; IHRCRC, 2015). In the past, pressure for reforms at the political level have been met with a tendency to structure feedback, accountability, and participation to benefit higher levels of decision-making (McCarthy, 2014; Nathan \& Boon, 2012). The creation of local democratic institutions has been argued to mask inequitable power relations while legitimating rent-seeking by public officials (Milne \& Adams, 2012b).

Given this rather bleak depiction of the political situation in rural Cambodia, it is remarkable that Community Forests now exist at nearly 500 sites across the country. By November 2016, however, only 50 of these had completed the full formalisation process, with 48 finalising this process in the preceding 18 months (Ratanakoma, 2016). In many respects, then, Cambodia's Community Forestry System (CFS) is in the early stages of development, despite more than a decade of policy commitment to CF devolution programmes (Forestry Administration, 2006) and a central role given to CF in local forest governance initiatives (FAO, 2010), for instance the national REDD+ programme (Forestry Administration, 2010).

From an historical perspective the evolution of the CFS appears to be far from straightforward. Indeed, several authors argue that the CF programme is simply an example of the RGC's strategy to maintain a façade of policy commitment while endorsing illicit activities in the forestry sector (Gritten et al., 2015; Milne \& Adams, 2012; Swift \& Cock, 2015). Lenient macroeconomic policies for agro-industrial development in the early 2000s coevolved with the dissolution of the forest concession system, giving rise to land conflicts across Cambodia (Chandet et al., 2010; Dhiaulhaq et al., 2014) and the acceptance and streamlining of the CF framework by international development agencies. In this context $\mathrm{CF}$ formalisation provided a means to achieve some minimal sense of tenure security, given the frequency of land-related conflicts and limited mechanisms for community empowerment at the time (Kurauchi et al., 2006), despite containing "rigid, complex and high-cost plans and regulations" (Kurashima, Matsuura, Miyamoto, Sano, \& Chann, 2015, p. 3092).

As Cambodia's CFS matures, CF sites will be expected to exhibit the institutional characteristics of effective forest governance by deterring powerful drivers of deforestation and overcoming pervasive governance constraints. CF formalisation seems to create a politically legitimate structure for stakeholders to support local forest users. It also ensures a degree of tenure security and legitimacy over customary use of forest resources, and devolves some decision-making powers to local user groups. So far, however, evidence on the performance of CF is inconclusive (Blomley et al., 2010; Loehr, 2012; Sunderlin, 2006), and the extent to which $\mathrm{CF}$ formalisation enables the emergence of durable institutions for 
collective action on forestry governance remains contested in the literature (Poffenberger, 2009; Pasgaard \& Chea, 2013; Nathan \& Boon, 2012). There is thus considerable variation across sites in their ability to successfully formalise CF and organise collective action activities, and the extent to which CF establishments enables the emergence of institutions capable of overcoming the above constraints remains highly uncertain.

A closer examination of CF creation and development would enable a more nuanced understanding of the institutional malaise that seems to characterise many $\mathrm{CF}$ sites. This article employs a mixed methods approach to evaluate capacities to engage in collective action on forest governance. It focuses on two questions. First, it assesses the extent to which CF creation and development leads to high rates of participation and awareness by local users through quantitative analysis. Through qualitative analysis, it examines the extent to which $\mathrm{CF}$ formalisation facilitates the emergence of durable institutions for collective action on forest governance.

The article has five further parts. The second section summarizes the theories the article applies to both primary and secondary data. The third section offers an overview of the methods conducted. Fourth, the article offers information on the fieldwork sites and qualitative findings. The fifth section present findings from a household survey. The sixth section discusses the relevance of the findings for theory. The seventh section concludes and draws out implications for policy. 


\section{Theoretical approach}

The theory used in this article draws on concepts from decentralisation, collective action and common pool resource governance as well as the institutional forms and incentives therein. Our starting point is that formal institutional arrangements do not guarantee representativeness and accountability as actors with incomplete information and decisionmaking rights must negotiate a complex field of accountability to produce public and private goods (Vuthy, 2006). At the local level, the co-existence of multiple institutions means that citizens and organisations face complex incentive structures for forest governance and use. Interventions will not necessarily favour effective forest governance, despite the existence of a formal mandate and body. Devolution programmes seeking to establish some form of comanagement regime may conceal broader authoritative tendencies or be fundamentally incompatible with de facto institutions for Natural Resource Management (NRM) in the local context, and there is a danger that user groups created via devolution programmes simply serve as a technocratic measure to increase efficiency and transparency rather than instil democratic governance (Larson \& Soto, 2008). Formal devolution of rights must therefore be distinguished from the transfer of meaningful and substantive discretionary powers to accountable and representative decision-making bodies (Ribot et al., 2006). In most experiences with co-management arrangements, property rights are only partially devolved to local community entities which, coupled with overbearing regulations and conditions imposed externally, present barriers to instituting an effective governance regime (Cronkleton et al., 2012; Larson \& Pulhin, 2012). This is particularly the case for commercial harvesting of forest resources.

A related theoretical strand focuses specifically on collective action in local Common Pool Resource (CPR) institutions. Although the incentives embedded in the prevailing institutional arrangements for CPR governance are often inadequate to overcome collective action problems (Bruns \& Chalad, 2004), the capacity to self-organise and govern a resource area exists (Ostrom, 1990). However, there are no blueprints for creating effective CPR institutions (Ostrom, 2004; Ostrom et al., 2007; Ostrom \& Nagendra, 2006), and policies to support locallevel institutions have been largely disappointing (Cronkleton et al., 2012; Larson \& Soto, 2008). Various models and frameworks have been developed to help explain the complex causal interactions between local CPR institutions and outcomes (Agrawal, 2001a), an example of which is the Institutional Analysis and Development (IAD) framework (Ostrom, 2005). The aim of the IAD framework is to identify and analyse the 'action arena' where participants make governance-related decisions, taking into account various exogenous and endogenous factors that influence governance effectiveness. The framework developed here is adapted from the IAD framework.

Building on the theoretical insights from the literature on CPR, researchers have identified a number of variables associated with effective CPR governance (Adhikari \& Di Falco, 2009; 
Clare Barnes \& van Laerhoven, 2015; Poteete \& Ostrom, 2004; Tucker \& Ostrom, 2005; Van Laerhoven \& Andersson, 2013; Van Laerhoven, 2010; see also Baynes et al., 2015, for a detailed literature review on community forestry). While many of these are not pertinent to CF (Van Laerhoven, 2010), autonomy from external influence in crafting and enforcing rules, the rate and intensity of external use and conflicts, and the organisation of monitoring, enforcement and maintenance activities have been emphasised as conducive of effective CF governance (Barnes \& Van Laerhoven, 2013; Baynes et al., 2015; Gibson et al., 2005; Hayes, 2006; Pagdee et al., 2006; Ratner et al., 2013; Tucker, 2010; Frank Van Laerhoven, 2010).

In terms of institutional development, Barnes \& van Laerhoven $(2015 ; 2013)$ highlight differences between emergence and durability of local collective action institutions. In other words, CF creation does not necessarily ensure that effective institutions, capable of adapting to evolving socioeconomic and political circumstances, will persist over time. On the level of the individual, Van Laerhoven (2010) identifies three collective action activities that individuals can participate in: (a) meetings and public spaces where CF rules and policies are deliberated; (b) monitoring and enforcement of rules; and (c) forest maintenance activities for commercial or conservation purposes. In the context of devolution programmes, it is critical that individuals have access to information to take advantage of potential opportunities (Larson \& Soto, 2008) and, once the CF is created, can access information related to collective action activities and the institutional structure of the CF including accountability relations (Tucker, 2010). Our conceptual framework incorporates these distinctions in addition to the individual incentives at play.

Incentives act through three channels in the context of CF. First, security of rights conferred by the particular co-management regime influence the viability of $\mathrm{CF}$ and prospects for generating long-term material benefits for CF members (Baynes et al., 2015; Larson \& Pulhin, 2012). The second aspect relates to the organisation of collective action activities. Individual costs and benefits from participating in meetings and public deliberation on $\mathrm{CF}$ will depend on prevailing gender norms and the household's socioeconomic circumstances. In general, participation in CF activities creates private costs while producing public goods for the user group. Specifically, monitoring and enforcement creates costs for both enforcers and rule violators, while ensuring the forest area is not overharvested (Gibson et al., 2005). Lastly, basic maintenance activities improve supply of forest resources for users over time, and added value through organised commercial management generates long-term benefits for members (Baynes et al., 2015).

The third aspect relates to how the CF institution in a particular community is embedded within evolving de facto institutional arrangements that influence incentives for forestland conversion and resource use, especially in relation to the expansion of markets and the underlying property rights system (Tucker, 2010). Related decision-making processes may be influenced by patron-client relationships, expectations and incentives for local development planning, opportunities provided by the local labour and goods markets, and the level of complementarity between the $\mathrm{CF}$ and traditional governance institutions. In the absence of effective institutions, these will lead to intensified use by external users, for which external 
conflict resolution and strong enforcement mechanisms are needed, or by internal users, requiring additional incentives to counteract degradation activities. Moreover, creating opportunities for cross-institutional communication and improving feedback and institutional incentives (Bixler, 2014, p. 158) helps to foster adaptive learning (Berkes, 2010).

The theoretical framework in Figure 1 summarises the above discussion in terms of factors that enable the emergence and durability of collective action institutions for CF. Processes related to the CFS that establish the particular co-management regime occur mainly at higher levels of policy, which help to structure the interaction between the CF entity and local forest users in terms of accountability and representativeness. Formalisation and organisation of collective action activities indicate existence of a basic CF structure, but other factors relating to participation by CF members and competition for the forestland and its resources, as well as regulations and conditions imposed on the $\mathrm{CF}$, influence the likelihood of durable collective action institutions emerging. Competition from external users is influenced by the organisational power of the competitor and the de facto institutional arrangements for land and forest areas. Meanwhile, on the individual level, characteristics such as remoteness, wealth, and education are expected to influence capacities to access information and associated costs and benefits of participation. The conceptual framework shows the two questions investigated in this article (Q1 and Q2). For Q1, the article focuses on participation in $\mathrm{CFs}$, the individual-level costs and benefits of participation and information dissemination mechanisms. This has been investigated using quantitative analysis from a structured questionnaire. For Q2, the article investigates formalisation and the level of external use, conflict and competition through a qualitative approach. 

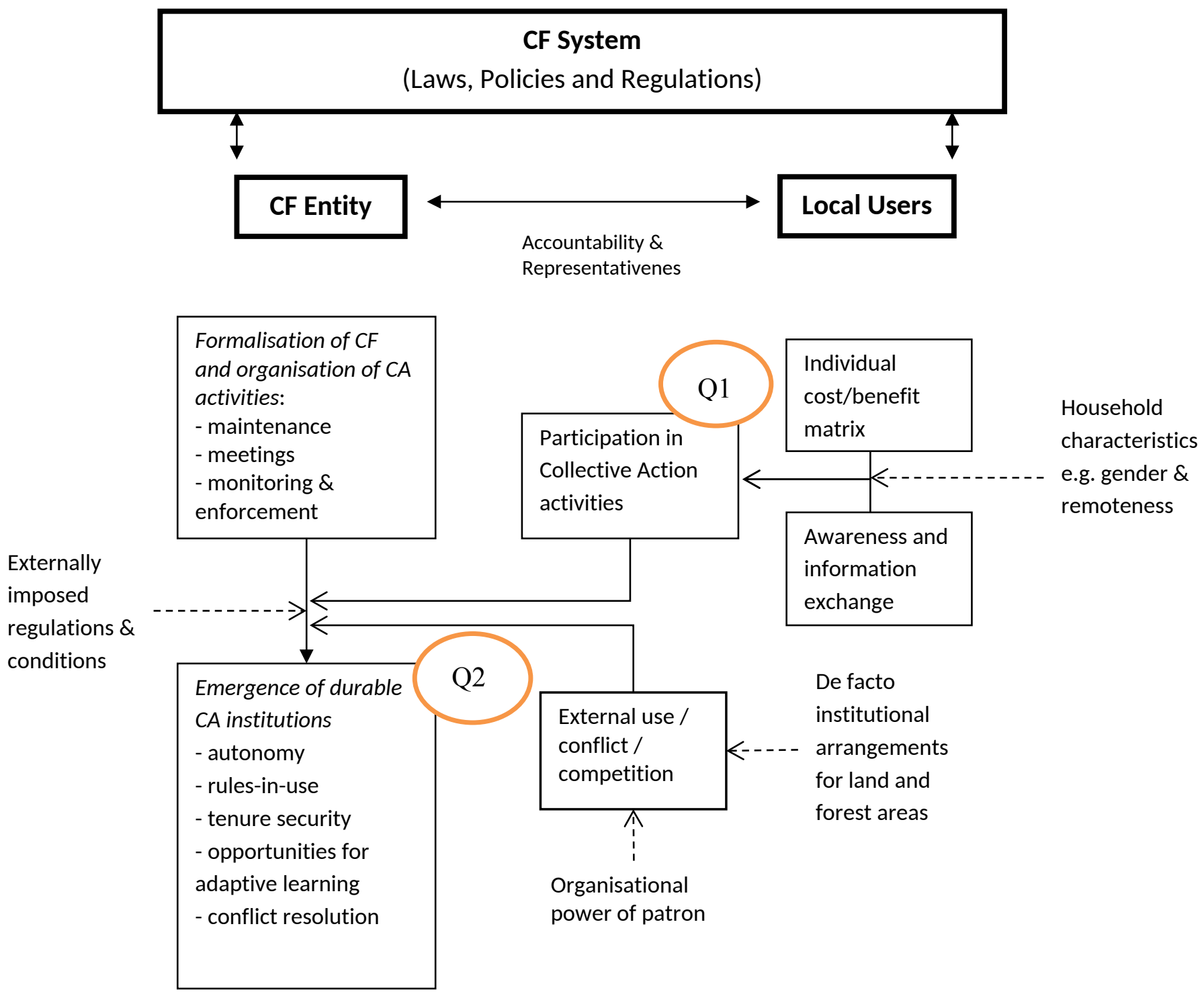
This article is based on primary data that was collected from a range of sources using both quantitative and qualitative methods. Although mixing methods required trade-offs, particularly given the time and resource constraints of the study, the choice was dictated by the research questions and the multifaceted nature of institutions. Background literature (especially Barnes \& van Laerhoven, 2015; Van Laerhoven \& Andersson, 2013) and methods guides from interdisciplinary research programmes on forestry institutions (including IFRI, 2013) provided important input to the design of the interview guides and household questionnaire.

Kratié province was chosen due to the intensive deforestation rates and rapid expansion of CF sites. The qualitative data was gathered using semi-structured in-depth and short interviews with stakeholders. Table 1 summarises the respondents for the qualitative interviews which were designed to investigate the second research question. ${ }^{2}$ The qualitative data enabled the construction of a comparative case study of two neighbouring $\mathrm{CF}$ sites (CF A and CF B) regarding their institutional characteristics and interaction with the policy frameworks and exogenous variables. The sites were chosen for three reasons. First, they had both nearly completed the formalisation process. Second, they are in close proximity to each other within the same commune. This enabled exploration of site-specific variables that influence $\mathrm{CF}$ governance, holding higher-level variables constant. Third, based on key informant interviews they seemed to be representative cases of CF creation and development.

The institutional components covered in the interviews provide indications of organisation and success of collective action activities as well as the CFs' interaction with policy and institutional environment. The qualitative interviews also sought to explore the extent to which the characteristics of durable collective action institutions are reflected in the CF sites. NVivo was used to analyse the data according to related themes. Pre-coding of initial themes was based on preliminary reading of the data and the literature review. Detailed reading of interview notes led to modification and addition of nodes to facilitate deeper analysis.

\footnotetext{
${ }^{2}$ Interviews lasted between 20 and 90 minutes, depending on the participant and the subject matter. These were conducted in English or using a translator, and recorded via note-taking. QSR NVivo 10 was used to process and analyse the data.
} 
Table 1 - Summary of respondents for qualitative research

\begin{tabular}{|c|c|c|c|}
\hline Context & \multicolumn{2}{|c|}{ Position (no. of partic.) } & Main topic(s) covered \\
\hline \multirow[t]{3}{*}{ Capital } & \multicolumn{2}{|c|}{$\begin{array}{l}\text { Department for CF, Forestry } \\
\text { Administration (2) }\end{array}$} & CF framework and formalisation process \\
\hline & \multicolumn{2}{|c|}{ NGO Representatives (2) } & Experiences with CF framework \\
\hline & \multicolumn{2}{|c|}{ External Stakeholders (3) } & Views on CF framework \\
\hline \multirow[t]{3}{*}{$\begin{array}{l}\text { Provincial } \\
\text { Town }\end{array}$} & \multicolumn{2}{|c|}{$\begin{array}{l}\text { Forestry Administration } \\
\text { Cantonment (1) }\end{array}$} & Regulations and policies on CF \\
\hline & \multicolumn{2}{|c|}{ Local NGO Representatives (6) } & $\begin{array}{l}\text { Approach to CF; collaboration with the } \\
\text { Forestry Administration, challenges and } \\
\text { issues; }\end{array}$ \\
\hline & \multicolumn{2}{|c|}{$\begin{array}{l}\text { Provincial Meeting (Participant } \\
\text { Observation) }\end{array}$} & $\begin{array}{l}\text { Experience of and challenges to CF in } \\
\text { province }\end{array}$ \\
\hline \multirow{2}{*}{$\begin{array}{l}\text { Commune } \\
\text { level }\end{array}$} & \multicolumn{2}{|c|}{ Commune Council Chief (1) } & Support and links to CF sites \\
\hline & \multicolumn{2}{|c|}{ Local extension worker (1) } & $\begin{array}{l}\text { Support to CF; roles/ responsibilities; } \\
\text { conformance with formal procedures }\end{array}$ \\
\hline \multirow[t]{3}{*}{ Village level } & CF A & CF B & \\
\hline & CF chief (1) & CF chief (1) & $\begin{array}{l}\text { Institutional components: meetings; } \\
\text { activities; enforcement; disputes; } \\
\text { information dissemination; membership; } \\
\text { rules; etc. }\end{array}$ \\
\hline & $\begin{array}{l}\text { CF committee } \\
\text { members (2) }\end{array}$ & $\begin{array}{l}\text { CF committee } \\
\text { members }(2)\end{array}$ & Institutional components: as above \\
\hline
\end{tabular}

The quantitative component, on the other hand, aimed to investigate the first research question by aggregating data across the two CF sites. Quantitative data was collected using a structured questionnaire with closed questions administered to 137 households, which included both members and non-members of the local CF. The questionnaire was translated into Khmer and enumerators completed the data collection. Respondents were asked a range of questions about their household characteristics, forest use patterns and engagement with the CF entity. The choice of variables in the model was based on literature that indicated characteristics including gender, household remoteness (where we used distance to the nearest market and national road), wealth (the proxy for which was land under cultivation), forest dependency (here we used the number of days in the forest), self-assessment of relative wellbeing, and engagement with public life (where we used attendance at village meetings as a proxy) were relevant to understanding participation in collective action activities and engagement with $\mathrm{CF}$.

Descriptive, univariate analyses were conducted to ascertain a general picture of the dataset. The theoretical background argued for the importance of awareness and information and exchange mechanisms for devolution programmes and collective action. Multivariate analysis 
therefore examined the relationship between household characteristics, participation in $\mathrm{CF}$ meetings and being informed about the CF through logistic regression and OLS models, respectively. The dependent variable for the OLS models was a self-reported measure of being informed about the CF activities on a scale of $0-100$. Fourteen missing values were managed by interpolation and given the mean value. Bivariate correlations with greater than $90 \%$ significance were included in the OLS models. ${ }^{3}$ Both numeric and categorical variables expected to exhibit a relationship were tested. ${ }^{4}$

\section{Fieldwork sites and qualitative findings}

Kratié province is located in the northeast region of Cambodia, bordering Vietnam on its south-eastern tip. The province is abundant in natural resources. The Mekong River flows through its centre and part of the Prey Lang forest landscape covers the Northeast. The province has experienced rapid deforestation in recent years, largely driven by a number of Economic Land Concessions (ELCs). Forest cover dropped from $78 \%$ of total land area to $55 \%$ between 2009 and 2014 (ODC, 2015). Notably, dense forest cover fell by more than half during this period. At the same time, $\mathrm{CF}$ is expanding with 45 established sites that cover 9.4\% of total forest area. Of these, 26 had signed a CF Agreement at the time of data collection, and six had completed the formalisation process. Sixteen CF sites had not been officially recognised and therefore had no legal mandate to protect the forest. Although not operational, two forest concessions inhibited the establishment of potential CF sites within these areas. The rest of this section offers findings on the second research question based on qualitative research methods.

CF sites in the province face challenges from illegal logging, demand for agricultural land, and low governance capacities. Specific challenges include poor cooperation between local communities and stakeholders, non-responsive local officials, illegal loggers threatening CF members (with backing from powerful political or commercial actors) and logging taking place at night. A number of strategies have been suggested to improve CF capacities. These include working closely with Forestry Administration (FA) and Commune Council (CC),

\footnotetext{
${ }^{3}$ The OLS models did not violate homoscedasticity. Three bivariate relationships exhibited high multicollinearity: Age and years in village; sex and household head; village of residence and distance to local market. Age and household head were dropped from the model. Since geographically the two main villages surveyed overlap, distance to market was retained rather than village of residence to improve clarity in the relationship with distance to local market. Bivariate correlations between the remaining independent variables are all below 0.350 . The regression standardised residual scatter plot tells us that there are no major outliers, since all points are within 2.5 standard deviations. A 45 degree normal P-P plot and the histogram of the regression standardised residual indicate that the distribution is normally distributed. There was limited multicollinearity in the final model with VIFs of remaining variables below 1.6.

${ }^{4}$ For categorical variables, means were compared to find the strength of correlation $\left(\mathrm{chi}^{2}\right)$. For continuous variables, an independent samples t-test and Levene's test for equality of variances were conducted to determine whether the relationship is significant and test for equal variance between groups. For variables with three or more groups, a one-way ANOVA and test of homogeneity of variances, followed by a post hoc test, were conducted.
} 
installing placards and poles to deter deforestation activities, making better equipment available to patrollers, and building a small moat around the CF. The FA follows policies outlined in the National Forest Programme (NFP) and the National Community Forestry Programme, but prioritises forestland conversion that result from private interests surrounding the CF. Two important policy developments have recently taken place at the provincial level.

First, created in 2012, the Community Forestry Network (CFN) consists of one CF committee member representing the interests of their constituents at each administrative level: village, commune, district, and province. The CFN acts as a bridge between individual CF sites and FA and focuses on resolving enduring governance issues. Problems are reported to CFN representatives who consult with FA officials to resolve practical or institutional issues. The idea is to create a bottom-up system of data and information generation that can help solve issues at higher levels.

Second, the Provincial Community Forest Programme Coordinating Committee (PCFPCC), created in 2012 and headed by the FAC Chief, coordinates with the CFN to resolve governance issues. Data and information generated by the different stakeholders are presented and discussed during general meetings to address policy gaps and law enforcement at the provincial level. For example, the CFN might approach the PCFPCC to resolve conflicts that could not be resolved at lower levels. If the issue cannot be resolved, the case is sent to Forestry Administration Cantonment (at the provincial level) and the provincial governor for adjudication, through which they bypass the formal court system. The PCFPCC also acts as a coordination mechanism between stakeholders and as a means for information sharing. The purpose of these new institutional structures is partly to circumvent legal and political mechanisms that do not function properly due to negligence and corruption. For example, during the first PCFPCC meeting, CF committees and the CFN committee were encouraged to approach the FAC directly when lower-level offices were non-responsive.

The commune features five villages in total and two CF sites. The major threats to forests in the area are firewood collection for private use and for charcoal, cutting down trees to build pepper farms, and CF encroachment. There is one official agro-industrial ELC in the commune, covering 6,400 hectares. The major income-generating activities are small-scale farming, operating a small informal enterprise, and logging and/or transporting wood products. Timber is transported from ELC areas to local markets or to the Vietnamese border. In the two villages studied, an estimated $50-60 \%$ of households earn a part of their income from logging activities. Details of the institutional aspects of CF A and CB B are summarised in Table 2. These were generated from interviews on the commune and village level. 


\begin{tabular}{|c|c|c|}
\hline & CF A & CF B \\
\hline Activities & $\begin{array}{l}\text { - Mainly patrolling and reporting forest crimes } \\
\text { - } \quad \text { Organises regular patrols } \\
\text { - } \quad \text { Aware of CFMP* } \\
\text { - No income-generating activities planned }\end{array}$ & $\begin{array}{l}\text { - Mainly patrolling and reporting forest crimes } \\
\text { - } \quad \text { Ad hoc patrolling } \\
\text { - Unaware of CFMP in development } \\
\text { - No income-generating activities planned }\end{array}$ \\
\hline Meetings & $\begin{array}{l}\text { - } \quad \text { Meetings held regularly but subject to availability } \\
\text { - In local FA office } \\
\text { - } \quad \text { Usually 20-30 participants }\end{array}$ & $\begin{array}{ll}\text { - } & \text { Irregular meetings } \\
\text { - } & \text { Held next to CFMC } * * \text { chief's house } \\
\text { - } & \text { Usually } 20 \text { participants }\end{array}$ \\
\hline Enforcement & $\begin{array}{ll}\text { - } & \text { Follow formal procedures except when relatively small-scale } \\
& \text { violation } \\
\text { - } & \text { No distinction between external and internal violators } \\
\text { - } & \text { Source of pressure mainly external to village } \\
\text { - } & \text { Estimated } 30 \text { violations (6 large-scale) in past year } \\
\end{array}$ & $\begin{array}{l}\text { - Follow formal procedures except when relatively small-scale } \\
\text { violation } \\
\text { - No distinction between external and internal violators } \\
\text { - Source of pressure both internal and external to village }\end{array}$ \\
\hline $\begin{array}{l}\text { Disputes } \quad \& \\
\text { Dispute Resolution }\end{array}$ & $\begin{array}{l}\text { - No internal disputes registered, but dissatisfaction with } \mathrm{CF} \\
\text { expressed; } \\
\text { - External dispute with district governor: a politically sanctioned } \\
\text { construction project took precedence }\end{array}$ & $\begin{array}{l}\text { - No internal disputes registered, but dissatisfaction with } \mathrm{CF} \\
\text { expressed } \\
\text { - Resolution mechanisms were ineffective in resolving an external } \\
\text { dispute with an ELC }\end{array}$ \\
\hline $\begin{array}{l}\text { Information } \\
\text { Dissemination }\end{array}$ & $\begin{array}{l}\text { - } \quad \text { Through word of mouth, meetings or workshops } \\
\text { - No awareness raising activities }\end{array}$ & $\begin{array}{l}\text { - Via mobile phone or during patrols; administrative costs } \\
\text { constrained information dissemination } \\
\text { - No awareness raising activities }\end{array}$ \\
\hline $\begin{array}{l}\text { Relationship with } \\
\text { external actors }\end{array}$ & $\begin{array}{ll}\text { - } & \text { Good relationship with local FA and CC } \\
\text { - } & \text { Support from CC only for dispute resolution } \\
\text { - } & \text { Close proximity to local FA office and CC chief } \\
\text { - } & \text { Perception of tenure security very weak } \\
\text { - } & \text { NGOs play a decisive role in CF development } \\
\end{array}$ & $\begin{array}{ll}\text { - } & \text { Good relationship with local FA and CC } \\
\text { - } & \text { Support from CC only for dispute resolution } \\
\text { - } & \text { Perception of tenure security very weak } \\
\text { - } & \text { NGOs play a decisive role in CF development }\end{array}$ \\
\hline CF Membership & \multicolumn{2}{|c|}{$\begin{array}{ll}\text { - } & \text { External users not represented } \\
\text { - } & \text { Intra-household conflicts of interest in CF governance present } \\
\text { - } & \text { Membership does not necessarily reflect perception of legitimacy or interest in effective CF governance }\end{array}$} \\
\hline $\begin{array}{l}\text { Rules } \quad \& \\
\text { Regulations }\end{array}$ & \multicolumn{2}{|c|}{$\begin{array}{l}\text { - } \quad \text { Rule violations by internal users occur frequently mainly due to lack of awareness of rules } \\
\text { - } \quad \text { No specific limit for harvesting resources had been established }\end{array}$} \\
\hline
\end{tabular}


This section investigates the relationship between household variables and $\mathrm{CF}$ engagement in the context of the two CF sites and is based on quantitative data. It offers findings on the first research question. After presenting descriptive statistics, findings from a logistic regression on participation in formal CF meetings are presented prior to two OLS regression models which examine the importance of informality connected to the relationship between access to information on $\mathrm{CF}$ and household variables. Turning to the descriptive statistics, respondents were somewhat equally distributed by gender ( $45.3 \%$ men, $55.7 \%$ women) with a mean level of education of four years. Households owned just under a hectare of land and were all Khmer. On average, respondents had lived in the village 29 years, lived 545 meters from a main road and $2.3 \mathrm{~km}$ from a market. Based on a self-reported scale 1-100, the mean subjective assessment of the household's relative standing in the village was 43.5 , with a median of 40 and a standard deviation of 14.7. Households' interaction with the forest varied considerably. Whilst 31\% never collect any Non-Timber Forest Products (NTFPs), 45\% visit the $\mathrm{CF}$ up to 12 times a year, $22 \%$ enter the $\mathrm{CF}$ once per month and $23 \%$ at least once per week. The main NTFP collected is firewood. On average, households earn 13\% of income from NTFP. Households' engagement with the CF also varied considerably. Measured on a scale of $0-100$, respondents' average level of awareness on CF activities, rules and structure was reported as 45 . Only $37 \%$ of the sample were members of one of the CFs, whilst $87 \%$ of respondents wanted the community forest to continue. Around $86 \%$ of respondents had attended less than three CF meetings in the last year whilst $10 \%$ were highly involved having attended between 3 and 10 meetings. Notably, respondents were asked 7 tripartite categorical questions (yes/no/don't know) about the rules and associated rights and responsibilities of the community forest: $49 \%$ scored 3 or less; $28 \%$ scored 4 ; and $16 \%$ scored 5 . Only $5 \%$ scored 6 or 7, indicating a considerable lack of understanding and awareness of how CFs function (see Appendix 1).

To get a full understanding of access to information, we conducted a logistic regression to assess the probability of attending CF meetings. We then extended this line of enquiry to assess informal access to information about community forestry through two OLS models. Table 3 shows the coefficients from the logistic regression model. Table 3 shows how, ceteris paribus, being older by one year increases the likelihood of attending meetings by $3 \%$ (significant at the $10 \%$ level), being a man increases the chances of attending by $50 \%$ (but without significance), and that each extra hectare of land owned increases the probability of participation by $75 \%$ (significant at the $99 \%$ level). Moreover, each extra day spent in the CF collecting products increases the likelihood of participation by $10 \%$ (significant at the $95 \%$ level). Overall, older households with more land and who collect products in the community forest are more likely to participate in meetings. But these findings only show participation in formal CF meetings. To differentiate between the formal information mechanisms and informal characteristics that may influence information access, a hierarchical multiple regression was conducted (Pallant, 2011, p. 149). 
Table 3 - Coefficients for logistic regression model

\begin{tabular}{|c|c|c|c|c|c|c|}
\hline & $\mathrm{B}$ & S.E. & Wald & df & Sig. & $\operatorname{Exp}(B)$ \\
\hline Age &, 026 &, 015 & 2,870 & 1 & ,090 & 1,026 \\
\hline Gender & ,410 & ,392 & 1,091 & 1 & ,296 & 1,506 \\
\hline \begin{tabular}{|l|} 
Relative wellbeing \\
on scale of $0-100$
\end{tabular} &,- 010 & ,013 &, 523 & 1 & ,469 & ,990 \\
\hline Land (hec) &, 560 & ,212 & 6,982 & 1 & ,008 & 1,750 \\
\hline $\begin{array}{l}\text { Days in the CF in } \\
\text { the past year }\end{array}$ & ,099 & ,048 & 4,251 & 1 & ,039 & 1,104 \\
\hline Constant & $-1,994$ & ,899 & 4,925 & 1 &, 026 &, 136 \\
\hline \multicolumn{7}{|c|}{ Dependent variable - Participation in 1 or more CF meetings in the past 12 months } \\
\hline
\end{tabular}

Two OLS models were run. The first OLS model included CF membership and attendance at CF meetings. The second model also evaluates the influence of the individual characteristics on the dependent variable. Recall, the dependent variable for the OLS models was a selfreported measure of being informed about the CF activities on a scale of $0-100$. Overall, both models are significant with a $\mathrm{p}$-value $<0.001$. The explanatory power of the final model is quite low, with an adjusted $\mathrm{R}^{2}$ of 0.287 , meaning that $28.7 \%$ of the variance observed in the sample can be explained by the variables in the model. This is an increase from an $\mathrm{R}^{2}$ of 0.172 in the first model. This increase suggests that individual characteristics influence access to information on $\mathrm{CF}$, even when taking into account formal membership and attendance at $\mathrm{CF}$ meetings. Table 4 presents the coefficients of the models. Once informal characteristics are included, and holding participation in community meeting and other variables constant, being a man and having higher relative well-being significantly increases being informed about the $\mathrm{CF}$ activities. To summarize, then, above and beyond attendance at meetings (which are dominated by older households with more land and an active interest in harvesting products from the forest), being a man and being wealthy significantly increases access to informal information mechanisms on CF activities. 
Table 4 - Coefficients of OLS models

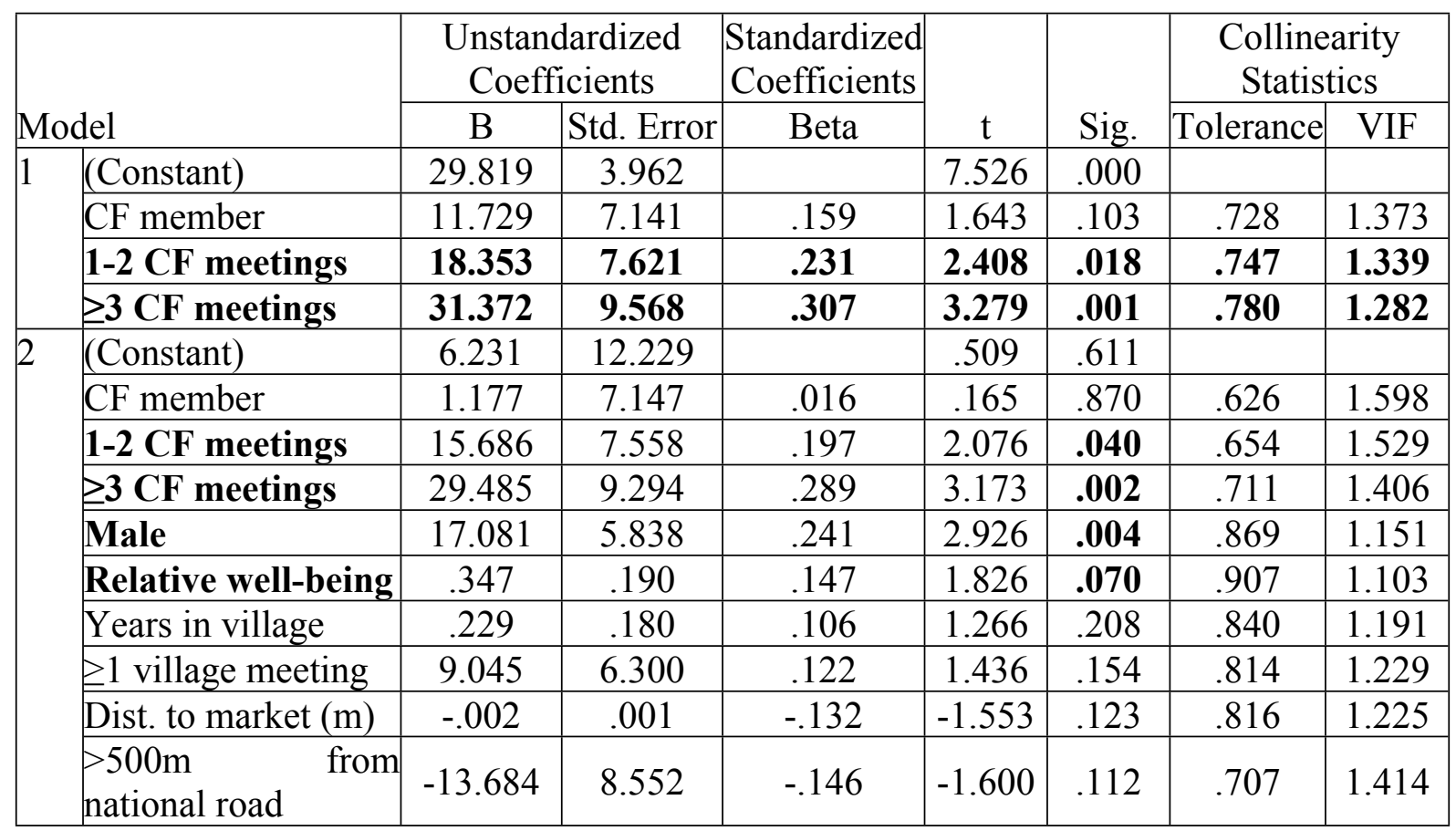




\section{Discussion}

To assess the extent to which CF creation and development has led to higher rates of participation and awareness by local users, this section focuses on participation, the individual-level costs and benefits of participation, and the information exchange mechanisms (see Q1 in Figure 1). Findings from the household survey show that not all members participate in $\mathrm{CF}$. The high proportion of members that had been to fewer than three meetings in the past year suggest that general engagement in CF is low. Participation is associated with general engagement in village matters, indicated through participation in village meetings, and an elite group seems to be sustaining the CF organisation. Moreover, CF membership does not seem to correspond to interest in effective forest governance for two reasons. First, a group of members gain an income from extractive forest engagement. While they may follow the rules of their own CF, these individuals leak forest use pressures to other areas. Second, a group of members do not rely on NTFPs at all. While high membership rates may signal internal community cohesion and political legitimacy, formal membership indicates little about individual incentives in effective forest governance. Collective action activities will only be effective if the incentives for effective forest governance for different groups are addressed.

Incentives for participation in collective action activities, in the form of costs and benefits, are limited for the average user. CF creation requires individuals to become members of the $\mathrm{CF}$ in order to retain customary user rights, but conforming to the rules of the CF entails very high costs. The regulations imposed on the CF include highly cumbersome procedures for timber and NTFP harvesting, whether for customary use or commercial sale. The resulting lack of opportunities to commercialise forest products incentivises leakage to forest areas where de facto open access persists (Blomley et al., 2010). Prospects for benefits within the CF are in general highly restrictive. Policies for CFs emphasise the importance of enhancing incomegeneration other than from the community forest, and the legal framework make references to alternative channels for commercialisation. However, income-generation is framed exclusively in terms of the heavily circumscribed CF Management Plan (CFMP). By restricting opportunities for generating endogenous benefits, the CFS perpetuates dependence on external sources of funding. Hence, the only direct opportunities granted through CF membership are through affiliation with and funding from civil society. Evidence suggests that the core group of elite members mentioned above maintain a superficial level of engagement with the $\mathrm{CF}$ in order to reap the long term benefits of $\mathrm{CF}$ formalisation once the entity gains access to funds for implementing activities via, for example, the national REDD+ programme.

Accessible information on rules, opportunities and governance arrangements of the $\mathrm{CF}$ is critical to ensure local users are able to engage in governance-related activities and uphold formally inscribed accountability relations. While access to information is a necessary condition for participation, it is not sufficient, as structural social and economic barriers relating to gender and socioeconomic standing may inhibit participation (Pasgaard \& Chea, 2013). The findings of the study support this hypothesis. Overwhelmingly, actors rely on 
informal information exchange networks in the village context to disseminate information related to the $\mathrm{CF}$, including scheduling meetings and discussing benefits from the CFS. An overreliance on informal information exchange from the $\mathrm{CF}$ management committee to $\mathrm{CF}$ members increases the risk of elite capture, and furthermore risks systematically excluding socially stratified groups from CF governance.

Our findings suggest that access to information on CF is skewed. Formal membership does not equate to being informed and while regular meetings continue to serve as an important information channel, the gender of the respondent and relative well-being influences access to information. Findings from the household survey moreover suggest that the formal rules and procedures do not correspond to rules-in-use. By implication, the CF tends to neglect internal regulation and the enforcement of locally-adapted rules. In sum, individual costs and benefits associated with participation and individual ability to access information on CF are mediated by household characteristics such as gender and socioeconomic conditions that are likely to influence the extent to which users are able to participate in collective action activities.

We now consider formalisation as well as the level of external use, conflict and competition (see Q2 in Figure 1). The formalisation process enables CF entities to complete some minimal organisational formation. Maps and documents are created, governance arrangements are formalised, and a few large public meetings are conducted. However, our findings suggest that related processes do not necessarily enable collective action institutions to emerge. Based on the qualitative data, the variability in institutional functioning between the two CF entities shows that context-specific characteristics influence CF effectiveness. Neither CF had initiated systematic maintenance activities. Meetings were not held on a regular basis and different kinds of meetings were not distinguished from each other. Information exchange was informal and intermittent. Monitoring and enforcement was organised in an ad hoc manner in one case and was completely voluntary in both, with little attention to regulating internal use. Enforcement mechanisms did not distinguish between different types of users, applying the same procedures to internal and external users regardless of degree of violation. Finding resolutions overwhelmingly relied on voluntary contracts and external intervention by local authorities. Moreover, several aspects of the CF were not implemented, indicating that both CF sites exhibited limited institutional sophistication despite nearly completing the formalisation process five years after initiation.

CF sites in Cambodia are subject to a very high level of pressure and competition for forestland. The strategies suggested at the general provincial meeting to deter external use signal a degree of desperation in creating effective monitoring arrangements and continuation of de facto open access in many areas, despite existence of formal mandates. The high level of external use necessitates a close working relationship between the CF entity and external actors, especially the Commune Council and local FA office. Evidence from the case studies suggests that where such informal relationships are lacking, support for CF activities and enforcement may be left wanting. Moreover, the organisational power of patrons remains a major challenge and undermines the capacity of formal institutions to address governance dilemmas. In CF A, a conflict over a construction project between the local authority and the 
CF entity highlighted the subordinate powers of the Community Forest Management Committee (CFMC). These issues are mediated by the de facto institutional arrangements for land and forests which do not necessarily correspond to de jure authority centres. Development projects and use of land allocation mechanisms sanctioned by local authorities within the CF area pose a problem to CF institutional consolidation, given the lack of accessible recourse mechanisms, thereby undermining formalisation and consolidation efforts by CF.

While the legal framework makes provisions for adaptation of rules to local contexts of CF, indicating some level of autonomy, experience of regulating internal use are limited due to a high level of preoccupation with forest protection and reporting on forest crimes by $\mathrm{CF}$ members. Autonomy is furthermore constrained by the structure of the heavy burdens imposed on the $\mathrm{CF}$ and a dependence on external actors for funding and intervention. The excessive enforcement costs associated with CF suggest that there is significant structural resistance to the redistribution of power and access implied by the formalisation of property rights, propagating a situation of de facto open access. This is partly a result of the extent to which informal institutions and accountability relations influence decision-making processes in local institutional arrangements for public goods provision.

The case studies indicate that perception of tenure security over property rights is very weak as a result of regulations and conditions imposed on the CF entity and the historical proclivity of the government to reallocate forestland for commercial purposes. Both case studies show that the failure of formal resolution and recourse mechanisms to resolve conflicts has worsened perceptions of tenure security. Moreover, existing monitoring and enforcement arrangements within the $\mathrm{CF}$ sites suggest institutional oversimplification: the regulatory framework offers no opportunities for members to develop locally adapted mechanisms such as graduated sanctions, as all violations are addressed via the same measures which rely heavily on support from line agencies and local authorities. Opportunities for institutional innovation are thus constrained by the informal nature of rule creation and enforcement, and restrictive linkages with other authority units. Ineffective meetings, undemocratic mechanisms and restricted information exchange also serve to limit opportunities for adaptive learning. 


\section{Conclusion}

Applying a mixed methods approach using data from two CF sites in Cambodia, this article sought to explore the seemingly pervasive challenges facing local forest users to formalise institutional arrangements, organise collective action activities and consolidate customary and commercial property rights over a forest area in the context of pervasive governance constraints and commercialisation of forest resources. Community Forests provide an important model for local user groups with interests in forest governance to formalise engagement in collective action. However, as this article has argued, formalisation and organisation of basic $\mathrm{CF}$ activities is insufficient for enabling the emergence of durable collective action institutions on forest governance since the institutional arrangements corresponding to any particular co-management regime will have consequences for a group's capacity to define and pursue their collective interests. Attention to inter-institutional linkages, prevailing informal constraints on forest use, and diverging interests in forestland and resource use are necessary considerations for $\mathrm{CF}$ entities to institutionalise effective forest governance. Specifically, monitoring and enforcement arrangements, as well as distribution of associated burdens between stakeholders, should favour autonomy and create conditions for institutional innovation and adaptive co-management (Bixler, 2014). Finding the right institutional mix to unlock innovation in local governance arrangements requires experimentation and flexibility.

Forest governance arrangements are typically characterised by complexity in developing countries where informal constraints tend to shape patterns of forest interaction. Community Forestry must be recognised as embedded in wider de facto institutional arrangements for land and natural resource governance that influence prospects for effective forest governance. CF can come to play an important role in this schema by regulating internal use patterns through the gradual build-up of formal constraints and endogenous benefit streams, and is thus best regarded as an institutional arrangement that integrates sustainable forest management practices over the long-term. However, given the pressing concern of addressing pervasive deforestation and forest degradation in Cambodia, and the pervasive governance constraints that limit opportunities for collective action, $\mathrm{CF}$ will have minimal impact in its current form.

A number of policy suggestions flow from the arguments of this article. Two critical reforms related to monitoring and enforcement are suggested. First, to provide space for and encourage CF entities to develop locally adapted enforcement mechanisms, including graduated sanctions and record-keeping of violations. Applying the same standard procedures and treating rule violations as a crime incentivises enforcers to ignore formal procedures. Second, exempt the CFMC from obligations to protect the forest area from external drivers. In its current form, the CF entity is held accountable for forest loss they cannot realistically be expected to prevent. Attention could then be refocused to regulating internal use, coupled with (compensated) monitoring and reporting. The funds for monitoring and enforcement could come from the Commune Development Fund, which could be used to employ forest dependent households as guards. 
Given the low levels of awareness of CF rules and institutions, encouraging awareness raising activities beyond meetings that target all forest users would help improve awareness of rules and obligations for members. Such activities should avoid uni-directional information dissemination but offer opportunities for co-learning. In terms of sharing CF best practice and learning, the CF Network offers potential. However, in its current form it is mainly focused to facilitate information on deforestation drivers to flow from the bottom-up in order to enable state law enforcement of forest crimes. More emphasis needs to be put on horizontal and adaptive learning across $\mathrm{CF}$ sites.

In general, external facilitators including NGOs should focus on enhancing conditions for collective action and institutional learning in the community context, and move away from assisting technocratic formalisation (Baynes et al., 2015; IHRCRC, 2015). Particular attention should be paid to ensuring greater inclusion in decision-making processes, specifically focusing on remote and worse-off households and women, by improving information exchange mechanisms. For this, external facilitators and CFMC could explore alternative, cost-efficient options for information exchange.

Institutions are highly complex and fluid entities, requiring a substantial amount of empirical data to evaluate fully (VanWey et al. 2005). While ascertaining formal rules is relatively simple, mapping the rules-in-use is extremely difficult. Due to time and budget constraints, it was not possible to investigate all institutional aspects of CF creation and development. Although this study sought to assess the extent to which the institutional arrangements implied by the formal framework enhance capacities to deter forestland conversion and forest exploitation, the generation of primary data on forest conditions and an in-depth understanding of specific rules-in-use are areas for further research. 
Appendix 1 - Descriptive statistics

\section{Household Characteristics}

\begin{tabular}{|c|c|}
\hline $\begin{array}{l}\text { Sex of } \\
\text { respondent }\end{array}$ & $\begin{array}{l}\text { Respondents were somewhat equally distributed between male }(45.3 \%) \text { and } \\
\text { female }(55.7 \%) \text {. }\end{array}$ \\
\hline $\begin{array}{l}\text { Household } \\
\quad \text { size }\end{array}$ & $\begin{array}{l}\text { The household size ranges from one to eight. } 74 \% \text { of households had } 3-5 \\
\text { members. }\end{array}$ \\
\hline $\begin{array}{l}\text { Village of } \\
\text { residence }\end{array}$ & $\begin{array}{l}82 \text { and } 55 \text { households came from } \mathrm{CF} A \text { and } \mathrm{CF} B \text {, respectively, representing } \\
\text { an equal proportion }(30 \%) \text { of the populations in each village }\end{array}$ \\
\hline $\begin{array}{l}\text { Years of } \\
\text { education of } \\
\text { HHH }\end{array}$ & $\begin{array}{l}\text { Ranging from } 0-12 \text {, mean education was four years, with a median value of } \\
\text { three. } 75 \% \text { had six or fewer years, and nearly } 17 \% \text { had never attended any } \\
\text { education. }\end{array}$ \\
\hline $\begin{array}{l}\text { Years lived } \\
\text { in the village }\end{array}$ & $\begin{array}{l}\text { The mean value is } 29 \text { years. } 12 \% \text { had moved to the village in the past } 5 \text { years } \\
\text { or less. A standard deviation of } 16 \text { years implies that people have lived in the } \\
\text { village for a longer time. }\end{array}$ \\
\hline $\begin{array}{l}\text { Distance to } \\
\text { national } \\
\text { road }\end{array}$ & $\begin{array}{l}\text { Households are located close to the national road, with a mean of } 545 \text { meters. } \\
\text { A standard deviation of } 1,289 \text { meters and a median of } 20 \text { meters suggest a } \\
\text { huge variance with a negative skew. } 75 \% \text { of households live within } 50 \text { meters, } \\
\text { while only } 15 \% \text { live between } 500 \text { and } 5000 \text { meters. }\end{array}$ \\
\hline $\begin{array}{l}\text { Distance to } \\
\text { local market }\end{array}$ & $\begin{array}{l}\text { Average distance is } 2,332 \text { meters with a maximum of } 8,000 \text {. Again, with a } \\
\text { standard deviation of } 2,150 \text { meters and a median of } 1500 \text {, the variable is } \\
\text { negatively skewed with a relatively large variance. } 50 \% \text { live within } 1,500 \\
\text { meters and } 75 \% \text { within } 3500 \text { meters. }\end{array}$ \\
\hline $\begin{array}{l}\text { Relative } \\
\text { well-being }\end{array}$ & $\begin{array}{l}\text { This variable is a self-reported value between } 1 \text { and } 100 \text { based on a subjective } \\
\text { assessment of the household's relative standing in the village. The average } \\
\text { response was } 43.5 \text {, with a median of } 40 \text { and a standard deviation of } 14.7 .90 \% \\
\text { of households responded with } 50 \text { or less. }\end{array}$ \\
\hline $\begin{array}{l}\text { Total } \\
\text { landholding } \\
\text { size }\end{array}$ & $\begin{array}{l}\text { Total landholding size is small, with an average of slightly under } 1 \text { hectare } \\
\text { and a median } 0.6 \text { hectare. With a standard deviation of } 1.06 \text { and a maximum } \\
\text { of } 5 \text {, outliers pull up the average. } 75 \% \text { own less than } 1.05 \text { ha, and nearly } 25 \% \\
\text { responded having no land accessible for agriculture. Each household in the } \\
\text { sample claimed to own their land. }\end{array}$ \\
\hline $\begin{array}{l}\text { Income } \\
\text { generated in } \\
\text { the past } 12 \\
\text { months }\end{array}$ & $\begin{array}{l}\text { The value is an approximation of real income. A mean of } 3.77 \text { million } \\
\text { Cambodian } \text { Riel }^{5} \text { and a standard deviation of } 9.76 \text { million indicate a huge } \\
\text { variance in income levels. There are } 48 \text { missing values. }\end{array}$ \\
\hline $\begin{array}{l}\text { Attendance } \\
\text { at village } \\
\text { meetings }\end{array}$ & $\begin{array}{l}37 \% \text { of respondents had not attended a general village meeting in the past } \\
\text { year and } 75 \% \text { had attended three } 3 \text { or less. A small portion of respondents } \\
\text { were highly involved in village matters. }\end{array}$ \\
\hline
\end{tabular}

54,000 riel is approximately equivalent to one USD 
Ethnicity $\mid$ All households were of the dominant Khmer ethnicity

Days spent in the CF per month

Proportion of livelihood from forest resources

Income from forest products

\section{Forest Interaction}

$45 \%$ of respondents had not visited the forest to collect forest products (NTFPs) in the past month, while 31\% never collect any NTFPs. 22\% enter the CF approximately only once per month and another $23 \%$ enter between 2 and 5 days. The main NTFP collected is firewood.

Respondents were asked to approximate the proportion of household livelihood that came from forest products. The variable includes both subsistence purposes and for income generation. Dependence is quite low with an average response of 12.7 and a median of $5.46 \%$ responded that they do not rely on forest resources at all.

$18.2 \%$ responded that their household earned an income from forest products, most likely from logging and timber transportation activities. In other words, this income is likely sourced in areas outside the CF.

\section{CF Engagement}

Informed about the $C F$

CF Member

Disputes with other CF Members

CF continue or not?

Number of CF meetings in past 12 months

Number of correct answers
This is the dependent variable. Measured on a scale of $0-100$, it summarises the respondent's level of awareness on CF activities, rules and structure. The mean response was $45.25 \%$ answered 10 or less, while $75 \%$ answered 80 or less. A standard deviation of 35.9 suggests answers are skewed to the extreme values.

$37.2 \%$ of respondents, equivalent to 51 individuals, are members of their respective CFs.

Respondents did not register any disputes concerning the $\mathrm{CF}$ that had been pursued via formal channels. However, informally, some concerns were shared.

Asked whether they want the $\mathrm{CF}$ to continue, $86.9 \%$ of respondents answered yes, $2.2 \%$ answered no and $10.9 \%$ answered "Don't know."

$60 \%$ of respondents had not attended a CF meeting in the past year, and $86 \%$ had attended less than three. $10 \%$ of respondents are highly involved in the $\mathrm{CF}$, having attended between 3 and 10 meetings.

Respondents were asked 7 yes/no/don't know questions about rules and associated rights and responsibilities. $49 \%$ scored 3 or less, $28 \%$ scored 4 , and $16 \%$ scored 5 . Only $5 \%$ scored 6 or 7 . 


\section{Bibliography}

Adhikari, B., \& Di Falco, S. (2009). Social Inequality, Local Leadership and Collective Action: An Empirical Study of Forest Commons. European Journal of Development Research, 21(2), 179-194. https://doi.org/10.1057/ejdr.2008.16

Agrawal, A. (2001a). Common property institutions and sustainable governance of resources. World Development, 29(10), 1649-1672.

Agrawal, A. (2001b). The Decentralizing State: Nature and Origins of Changing Environmental Policies in Africa and Latin America, 1980-2000. In 97th Annual Meeting of the American Political Science Association, San Francisco, August (Vol. 30). Retrieved from http://www.yale.org/leitner/resources/docs/2001-18.pdf

Andersson, K. P., \& Ostrom, E. (2008). Analyzing decentralized resource regimes from a polycentric perspective. Policy Sciences, 41(1), 71-93. https://doi.org/10.1007/s11077-007-9055-6

Barnes, C., \& Van Laerhoven, F. (2013). Helping to self-help? External interventions to stimulate local collective action in Joint Forest Management, Maharashtra, India. International Forestry Review, 15(1), 1-17. https://doi.org/10.1505/146554813805927246

Barnes, C., \& van Laerhoven, F. (2015). Making it last? Analysing the role of NGO interventions in the development of institutions for durable collective action in Indian community forestry. Environmental Science \& Policy, 53, 192-205. https://doi.org/10.1016/j.envsci.2014.06.008

Bartley, T., Andersson, K., Jagger, P., \& Laerhoven, F. V. (2008). The Contribution of Institutional Theories to Explaining Decentralization of Natural Resource Governance. Society \& Natural Resources, 21(2), 160-174. https://doi.org/10.1080/08941920701617973

Baynes, J., Herbohn, J., Smith, C., Fisher, R., \& Bray, D. (2015). Key factors which influence the success of community forestry in developing countries. Global Environmental Change, 35, 226-238. https://doi.org/10.1016/j.gloenvcha.2015.09.011

Berkes, F. (2010). Devolution of environment and resources governance: trends and future. Environmental Conservation, 37(4), 489-500. https://doi.org/10.1017/S037689291000072X

Billon, P. (1999). Power is Consuming the Forest: The Political Ecology of Conflict and Reconstruction in Cambodia. University of Oxford.

Bixler, R. P. (2014). From Community Forest Management to Polycentric Governance: Assessing Evidence from the Bottom Up. Society \& Natural Resources, 27(2), 155169. https://doi.org/10.1080/08941920.2013.840021

Blomley, T., Tola, P., Kosal, M., Dyna, E., \& Dubois, M. (2010). Review of Community Forestry and Community Fisheries in Cambodia.

Bottomley, R. (2000). Structural Analysis of Deforestation in Cambodia (with a Focus on Ratanakiri Province, Northeast Cambodia). Mekong Watch and Institute for Global Environmental StrategiesNon-Timber Forest Products Project.

Bruns, B., \& Chalad, P. (2004). Strengthening Collective Action. Collective Action and Property Rights for Sustainable Development, Brief 15/16. Retrieved from https://dlc.dlib.indiana.edu/dlc/handle/10535/3916 
Chan, S., \& Sasaki, N. (2014). Assessment of Drivers of Deforestation and Forest Degradation in Phnom Tbeng Forest Based on Socio-Economic Surveys. Journal of Environmental Protection, 5(17), 1641-1653. https://doi.org/10.4236/jep.2014.517155

Chandet, H., Bampton, J. F., Kelley, L. C., \& Brofeldt, S. (2010). Whose land is this anyway? The role of collective action in maintaining community rights to the land in Kratie, Cambodia. In International Research Workshop on Collective Action, Property Rights, and Conflict in Natural Resources Management, Siem Reap, Cambodia (Vol. 28). Citeseer. Retrieved from http://citeseerx.ist.psu.edu/viewdoc/download?doi=10.1.1.365.7955\&rep=rep1\&type= pdf

Cronkleton, P., Saigal, S., \& Pulhin, J. (2012). Co-management in community forestry: How the partial devolution of management rights creates challenges for forest communities. Conservation and Society, 10(2), 91. https://doi.org/10.4103/0972-4923.97481

Davis, K. F., Yu, K., Rulli, M. C., Pichdara, L., \& D’Odorico, P. (2015). Accelerated deforestation driven by large-scale land acquisitions in Cambodia. Nature Geoscience, 8(10), 772-775. https://doi.org/10.1038/ngeo2540

Dhiaulhaq, A., Yurdi, Y., \& Gritten, D. (2014). Land grabbing and forest conflict in Cambodia: Implications for community and sustainable forest management. In Forests under pressure: local responses to global issues (pp. 205-216). International Union of Forest Research Organizations (IUFRO).

Ehara, M., Hyakumura, K., Nomura, H., Matsuura, T., Sokh, H., \& Leng, C. (2016). Identifying characteristics of households affected by deforestation in their fuelwood and non-timber forest product collections: Case study in Kampong Thom Province, Cambodia. Land Use Policy, 52, 92-102. https://doi.org/10.1016/j.landusepol.2015.12.006

FAO. (2010). Cambodia Forestry Outlook Study. FAO Regional Office for Asia and the Pacific.

Forestry Administration. (2006). National Community Forestry Programme Strategic Paper. Forestry Administration. (2010). REDD+ Roadmap (Readiness Plan) in Cambodia. Ministry of Agriculture, Forestry and Fisheries.

Forests Trends. (2015). Conversion Timber, Forest Monitoring, and Land-Use Governance in Cambodia. Forest Trends Report Series: Forest Trade and Finance.

GERES. (2015). Impact Assessment of Woodfuels Consumption on Deforestation and Forest Degradation in Cambodia. Group for the Environment, Renewable Energy, and Solidarity (GERES), Phnom Penh, Cambodia.

Gibson, C. C., Williams, J. T., \& Ostrom, E. (2005). Local Enforcement and Better Forests. World Development, 33(2), 273-284. https://doi.org/10.1016/j.worlddev.2004.07.013

Gritten, D., Greijmans, M., Lewis, S., Sokchea, T., Atkinson, J., Quang, T., ... Paudel, N. (2015). An Uneven Playing Field: Regulatory Barriers to Communities Making a Living from the Timber from Their Forests-Examples from Cambodia, Nepal and Vietnam. Forests, 6(10), 3433-3451. https://doi.org/10.3390/f6103433

Hayes, T. M. (2006). Parks, People, and Forest Protection: An Institutional Assessment of the Effectiveness of Protected Areas. World Development, 34(12), 2064-2075. https://doi.org/10.1016/j.worlddev.2006.03.002

Higginson, A., Bandeth, R., \& Sopheap, H. (2013). Assessment of the Second Term of Decentralisation in Cambodia: Commune Council Performance and Citizen's Participation, 2007-2012. Committee for Free and Fair Elections in Cambodia (COMFREL).

IFSR. (2004). Independent Forest Sector Review: The Forest Sector in Cambodia. 
IHRCRC. (2015). Seeding the Ground: Promoting Community Empowerment in Cambodia. International Human Rights and Conflict Resultion Clinic at Stanford Law School.

Kurashima, T., Matsuura, T., Miyamoto, A., Sano, M., \& Chann, S. (2015). Considering the Practical Rationality of Experimental Operation in Developing Countries: Reality and Challenges under a Rigid Community Forestry System in Cambodia. Forests, 6(9), 3087-3108. https://doi.org/10.3390/f6093087

Larson, A. M., \& Soto, F. (2008). Decentralization of Natural Resource Governance Regimes. Annual Review of Environment and Resources, 33(1), 213-239. https://doi.org/10.1146/annurev.environ.33.020607.095522

Larson, A., \& Pulhin, J. (2012). Enhancing forest tenure reforms through more responsive regulations. Conservation and Society, 10(2), 103. https://doi.org/10.4103/09724923.97482

Loehr, D. (2012). Land Reforms and the Tragedy of the Anticommons - A Case Study from Cambodia. Sustainability, 4(12), 773-793. https://doi.org/10.3390/su4040773

McCarthy, S. (2014). Norm diffusion and the limits to forestry governance reform in Southeast Asia's new democracies. The Pacific Review, 27(5), 755-778.

Milne, S. (2015). Cambodia's Unofficial Regime of Extraction: Illicit Logging in the Shadow of Transnational Governance and Investment. Critical Asian Studies, 47(2), 200-228. https://doi.org/10.1080/14672715.2015.1041275

Milne, S., \& Adams, B. (2012). Market Masquerades: Uncovering the Politics of Communitylevel Payments for Environmental Services in Cambodia: Politics of Community-level PES in Cambodia. Development and Change, 43(1), 133-158.

Miranda, M., \& Kool, J. (2007). Cambodia's Family Trees: Illegal Logging and the Stripping of Public Assets by Cambodia's Elites. Global Witness.

Nathan, I., \& Boon, T. E. (2012). Constraints and Options in Local Forest Management in Cambodia: Is Decentralization a Solution? Journal of Sustainable Forestry, 31(4-5), 396-420.

ODC. (2015, April 10). Open Development Cambodia - Forest Cover Study (1973-2014). Retrieved April 6, 2016, from https://cambodia.opendevelopmentmekong.net/issues/forest-cover/

Ostrom, E. (1990). Governing the commons : the evolution of institutions for collective action. Cambridge : Cambridge Univ. Press, 1990.

Ostrom, E. (2004). Understanding Collective Action. Collective Action and Property Rights for Sustainable Development, Brief 2/16. Retrieved from https://dlc.dlib.indiana.edu/dlc/handle/10535/3916

Ostrom, E. (2005). Understanding institutional diversity. Princeton, N.J. : Princeton University Press, cop. 2005.

Ostrom, E., Janssen, M. A., \& Anderies, J. M. (2007). Going beyond panaceas. Proceedings of the National Academy of Sciences, 104(39), 15176-15178.

Ostrom, E., \& Nagendra, H. (2006). Insights on linking forests, trees, and people from the air, on the ground, and in the laboratory. Proceedings of the National Academy of Sciences, 103(51), 19224-19231.

Pagdee, A., Kim, Y., \& Daugherty, P. J. (2006). What Makes Community Forest Management Successful: A Meta-Study From Community Forests Throughout the World. Society \& Natural Resources, 19(1), 33-52. https://doi.org/10.1080/08941920500323260

Pallant, J. (2011). SPSS survival manual: a step by step guide to data analysis using SPSS. Crows Nest, N.S.W.: Allen \& Unwin.

Park, C. M. Y. (2015). New "Webs of Power" and Agrarian Transformations in Cambodia: Where are the Women? BRICS Initiative for Criticial Agrarian Studies (BICAS). 

and Forest Protection in Local Communities in Northern Cambodia. Austrian Journal of South-East Asian Studies / Österreichische Zeitschrift Für Südostasienwissenschaften, 6(2), 330-355.

Poffenberger, M. (2006). People in the forest: community forestry experiences from Southeast Asia. International Journal of Environment and Sustainable Development, 5(1), 5769.

Poffenberger, M. (2009). Cambodia's forests and climate change: Mitigating drivers of deforestation. In Natural Resources Forum (Vol. 33, pp. 285-296). Wiley Online Library.

Poteete, A. R., \& Ostrom, E. (2004). Heterogeneity, group size and collective action: the role of institutions in forest management. Development and Change, 35(3), 435-461.

Ratanakoma, L. (2016, March). The 46th TWG-FR Meeting - Community Forestry (Progress for JMI 2014-2015). Phnom Penh. Retrieved from http://twgfr.org/meetings/twg-frmeeting.html

Ratner, B. D., Meinzen-Dick, R., May, C., \& Haglund, E. (2013). Resource conflict, collective action, and resilience: an analytical framework. International Journal of the Commons, 7(1), 183-208.

RGC. (2008). Law on Administrative Management of the Capital, Provinces, Municipalities, Districts and Khans.

RGC. (2010). National Program for Sub-National Democratic Development (NP-SNDD) 2010-2019. Royal Government of Cambodia.

Ribot, J. C. (2002). Democratic decentralization of natural resources: institutionalizing popular participation. Washington, DC: World Resources Institute.

Ribot, J. C., Agrawal, A., \& Larson, A. M. (2006). Recentralizing While Decentralizing: How National Governments Reappropriate Forest Resources. World Development, 34(11), 1864-1886. https://doi.org/10.1016/j.worlddev.2005.11.020

Strangio, S. (2014). Hun Sen's Cambodia. Silkworm Books.

Sunderlin, W. D. (2006). Poverty alleviation through community forestry in Cambodia, Laos, and Vietnam: An assessment of the potential. Forest Policy and Economics, 8(4), 386-396.

Swift, P., \& Cock, A. (2015). Traditional Khmer Systems of Forest Management. Journal of the Royal Asiatic Society, 25(1), 153-173.

Tucker, C. M. (2010). Learning on governance in forest ecosystems: Lessons from recent research. International Journal of the Commons, 4(2), 687-706.

Tucker, C. M., \& Ostrom, E. (2005). Chapter 4: Multidisciplinary Research Relating Institutions and Forest Transformations. In E. F. Moran \& E. Ostrom (Eds.), Seeing the forest and the trees: human-environment interactions in forest ecosystems (pp. 81104). Cambridge, Mass: Mit Press.

Un, K., \& So, S. (2009). Politics of Natural Resource Use in Cambodia. Asian Affairs: An American Review, 36(3), 123-138.

Van Laerhoven, F. (2010). Governing community forests and the challenge of solving twolevel collective action dilemmas-A large-N perspective. Global Environmental Change, 20(3), 539-546. https://doi.org/10.1016/j.gloenvcha.2010.04.005

Van Laerhoven, F., \& Andersson, K. P. (2013). The virtue of conflict: an institutional approach to the study of conflict in community forest governance. International Forestry Review, 15(1), 122-135. https://doi.org/10.1505/146554813805927219

VanWey, L. K., Ostrom, E., \& Meretsky, V. (2005). Chapter 2: Theories Underlying the Study of Human-Environment Interactions. In E. F. Moran \& E. Ostrom (Eds.), Seeing 
the forest and the trees: human-environment interactions in forest ecosystems (pp. 2356). Cambridge, Mass: Mit Press.

Vuthy, H. Conceptualising Accountability: The Cambodian Case, Cambodia Development Review, Cambodia Development Resource Institute, 10 (4), 2006, p. 6-8

Weingart, A., \& Kirk, M. (2008). Escaping Poverty Traps? Collective Action and Property Rights in Post-War Rural Cambodia. Working Paper No. 89. Collective Action and Property Rights (CAPRi).

Work, C. (2015). Intersections of Climate Change Mitigation Policies, Land Grabbing and Conflict in a Fragile State: Insights from Cambodia. Retrieved from http://www.iss.nl/fileadmin/ASSETS/iss/Research_and_projects/Research_networks/L DPI/CMCP_73-Work.pdf 